Article

\title{
The Effect of Consumers' Perceived Value on Acceptance of an Internet-Only Bank Service
}

\author{
Sang Joon Ahn ${ }^{1}$ and Seong Ho Lee ${ }^{2, *(\mathbb{D})}$ \\ 1 School of Management, Kyung Hee University, Seoul 02447, Korea \\ 2 Department of Business Administration \& Accounting, Hanbat National University, Daejeon 34158, Korea \\ * Correspondence: 1sh33@hanbat.ac.kr; Tel.: +82-42-821-1376
}

Received: 20 July 2019; Accepted: 21 August 2019; Published: 23 August 2019

check for updates

\begin{abstract}
This study focuses on perceived value, which is not mentioned in previous internet-only bank studies, to analyze the popularity of internet-only banks. It does this by exploring the relationships between the perceived value and usage intention of customers. The purpose of this study is to help us understand customers' decision making to accept innovative services by finding factors that affect consumer acceptance of internet-only banks. Using multiple regression, this study analyzes data gathered from college students in their 20s who are familiar with IT services and are interested in internet-only banks. The results show that all three components of perceived value (economical value, convenience value, and emotional value) increase usage intention. Convenience value is the most important factor in the acceptance of internet-only banking services. The findings indicate that perceived value is an attractive factor in using internet-only banks and suggest that managing and developing perceived value is an important marketing strategy.
\end{abstract}

Keywords: internet-only bank; perceived value; usage intention; customer acceptance

\section{Introduction}

Today, the internet distribution environment is changing rapidly and customers are increasingly using internet and mobile shopping. With increasing competition in the banking industry, banking services too have developed, undergoing various changes. Recently, the "KaKao Bank", an internet-only bank in South Korea, has become very popular among South Koreans. Launched in 2016, its banking services have the advantage of being under the umbrella of the "Kakao Corporation", which provides a well-known instant messaging service called "KakaoTalk". In about six months, Kakao Bank has gained over five million customers. Customers can open accounts in 10 minutes or less, after downloading a mobile application on their smartphones, and verifying their personal information. In its early days, the internet-only bank was not popular as a concept in the United States, with only 9.4 million customers opening bank accounts online, of which 3.1 million stopped service, primarily because of delays in service or poor customer service [1]. Therefore, understanding the popularity of internet-only banks in Korea will help this industry develop. In addition, despite its popularity among customers, few studies actually examine internet-only banking.

According to research that has studied the factors that affect the acceptance of internet-only banks, performance expectancy, effort expectancy, facilitating conditions, past experience with technology use, social influence, and perceived usefulness have increased the acceptance intention of internet-only banks [2-4]. Therefore, this study focuses on consumers' perceived value, which has not been covered by previous studies, and examines its impact on the acceptance of internet-only banks. Understanding the needs and expectations of customers wanting to use internet-only banks can provide some marketing insights to vitalize this industry. 
First, we examined the impact of perceived value on the adoption of online-only banking services, which prior studies failed to do. Second, we examine the reasons behind the significant popularity of internet-only banks and the effect of various perceived-value constructs in terms of bank services on usage intention. Third, we provide academic and managerial implications to contribute to the internet-only banking industry.

\section{Literature Review and Hypothesis Development}

\subsection{Internet-Only Bank}

Almost all banks use the internet to provide services to customers [5]. Primarily, there are two types of online banking in terms of internet dependence. The first type is the traditional offline bank, simply providing online access to its customers. These additional online channels may provide more convenience; however, they do not provide additional financial incentives. The second type, the internet-only bank, was created to satisfy customers who wished to access banking services using the internet, without ever having to visit physical branches [6].

The world's first internet-only bank, the Security First Network Bank, was launched in the United States in October 1995. Pure internet startups were expected to have lower operating costs because physical stores were not needed. Internet banking was also able to reduce operating costs by reducing the inefficiency of paper transactions, monthly statements, credit card statements, and bills [1].

The internet-only bank model offers advantages for both banks and their customers. An important financial characteristic of internet-only banking models is the reduction in overhead spending. By eliminating physical branches, banks can reduce the labor force required to operate branch offices, and among other things, lease (or mortgage repayments), maintenance, and maintenance work. Furthermore, banks can increase market share by paying higher interest on deposits or lowering lending rates. Customers benefit not only from increased convenience, but also because internet-only banks can use such overhead cost savings to give higher interest rates [7].

Prior studies have examined factors that influence customer acceptance of internet-only banks. Zhang et al. [8] analyze brand trust transfer between internet enterprises and their affiliated internet-only banks, and the effect of such transfer on the adoption behavior of customers. Their results show that brand trust in the internet enterprise increases initial trust in internet-only banks, which enhances the adoption of internet-only banking services. Therefore, brand trust in the internet enterprise can transfer initial trust in internet-only bank services through performance expectancy and perceived risk.

Kaabachi et al. [9] investigated consumer adoption of internet-only banks and the factors that influence initial trust in consumers. They suggested that consumer familiarity with internet banking, high perceived structural assurance, perceived website quality, bank reputation, and relative advantage are critical factors.

Japan Net Bank (JNB), an internet bank with no first physical location in Japan, started operations in October 2000. It has attracted young customers looking for convenient 24-h banking services with interest rates and transaction fees that are far more competitive than those offered by traditional Japanese banks [1].

\subsection{Perceived Value}

Generally, consumers tend to choose products and services that represent their value [10]. Value is a variable that can account for individual consumer behaviors and serves as criteria benchmark for consumer cognitive and behavioral processes. The importance of perceived value in customer decision making is well known. However, very few studies examine a variety of perceived values and their direct causal relationships with post-purchase behavior [11]. Customer-perceived value is defined as the customer's evaluation or overall assessment of the difference in perception between what is received and what is given [12,13].

In a departure from prior studies on customer value, Sweeney and Soutar [14] examined both hedonic and utilitarian value to understand and extend the concept of perceived customer 
value. The composition of customer value has four specific levels: the economic value of price, functional value of quality, emotional value, and social value. In explaining the purchase behavior of consumers, they argued that the multidimensional configuration concept could explain customer value in more detail than existing single-dimensional constructions. Pihlström and Brush [11] extended the multi-dimensional approach by adding a convenient value dimension to Sweeney and Soutar's [14] work. Using this, we demonstrated the direct effects of perceived value dimensions on consumer behavior, suggesting that examining perceived value in various dimensions could help identify the perception of specific consumer values.

Specifically, economic value refers to the monetary value that customers recognize in low prices or costs, over other alternatives, when purchasing products or services [15]. Consumers sense economic value when prices are reasonable or cheaper than the utility provided by products and services; the greater the difference, the greater the economic value they ascribe. In contrast, convenience value is the degree of ease with which a customer can purchase services and complete a transaction [14]. Convenience is associated with the effort and time spent to receive something, achieved by reducing the effort and time required for consumers to purchase and use a product or service. Third, emotional value is defined as the feelings or emotions caused by a product or service [15]. In other words, positive emotions emanating from fun and enjoyable service experiences when purchasing or consuming a product or service create emotional value. Finally, social values are defined by social acceptance and they reinforce social self-concepts formed by using products or services [14]. The concept of social value dictates that the motivation for purchasing and using a product depends on how a customer wants to look or appear to others $[14,15]$. In other words, social values represent the extent to which individuals can socially express their image to others by purchasing and using a product or service.

In this study, we used the perceived value dimension of Pihlström and Brush [11] to explore the impact of consumers' perception of these specific values on their behavior. However, as internet banking services are customized for individuals for whom security is important, and do not depend on information sharing and social networks, we focused on the following dimensions: economic value, emotional value, and convenience value.

\subsection{Perceived Value as a Determinant of Customer Acceptance of Internet-Only Banks}

Economic value is an important factor for using services. Customers that perceive to have received more financial value in using the service are more satisfied than those who do not [16]. In the retail service environment, Sweeney, Soutar and Johnson [17] found that the value of money had an important and positive effect on customers' willingness to purchase electric appliances.

In particular, monetary value will have a positive impact on using mobile services [11]. As it is a type of self-service without contact with staff, it can often reduce the cost of use for consumers. Thus, these small cost savings give consumers a sense of financial value [18].

In other words, an internet-only banking service, which eliminates physical outlets and provides customers with additional financial benefits over traditional banks without hiring a counter-employer, is expected to increase a customer's willingness to use it by providing economical value. Therefore, the following hypothesis is proposed.

Hypothesis 1. Economical value will have a positive effect on usage intention.

Van der Heijden [19] argued that the ease of using a service was an important variable for consumers, which they enjoyed and perceived as useful. Zhang and Prybutok [20] demonstrated that the convenience value provided by online services is an important factor in e-service success, and Meuter et al. [21] argued that such conveniences play an important role in enhancing user satisfaction through ease of use and simple processing. 
Reichheld and Schefter [22] argued that consumers are moving offline and online to gain more convenience value, not simply because of cheap prices. In other words, if consumers can use a convenient service, they have the means to pay a corresponding price.

Even consumers that hesitate in using internet-only banking services find this increase in convenience significant. Thus, greater convenience will increase the use of internet-only banks.

Hypothesis 2. Convenience value will have a positive effect on usage intention.

A product has emotional value if it relates to the consumer's emotions or triggers those emotions. Therefore, the enjoyment of purchasing and using products and services themselves relates to emotional value [23]. This positive emotion is an important factor in influencing usage intention, in the context of mobile services [24].

Emotional values also have an important impact, especially on consumers' adaptation to new technologies. Venkatesh et al. [25] demonstrated that perceived enjoyment plays an important role in adapting to new technology and positively influences the intention to use it. In summary, users that are emotionally satisfied with mobile applications are likely to have higher intended use.

In particular, "Kakao Bank", which is the target of this study, uses marketing to stimulate customer emotions through various additional services, TV commercials, and cute characters, called "Kakao Friends". This emotional approach can be the driving force behind successful market entry and development, unlike traditional Internet-only banks.

Hypothesis 3. Emotional value will have a positive effect on usage intention.

Based on the literature review, Figure 1 is a model of acceptance of internet-only bank services.

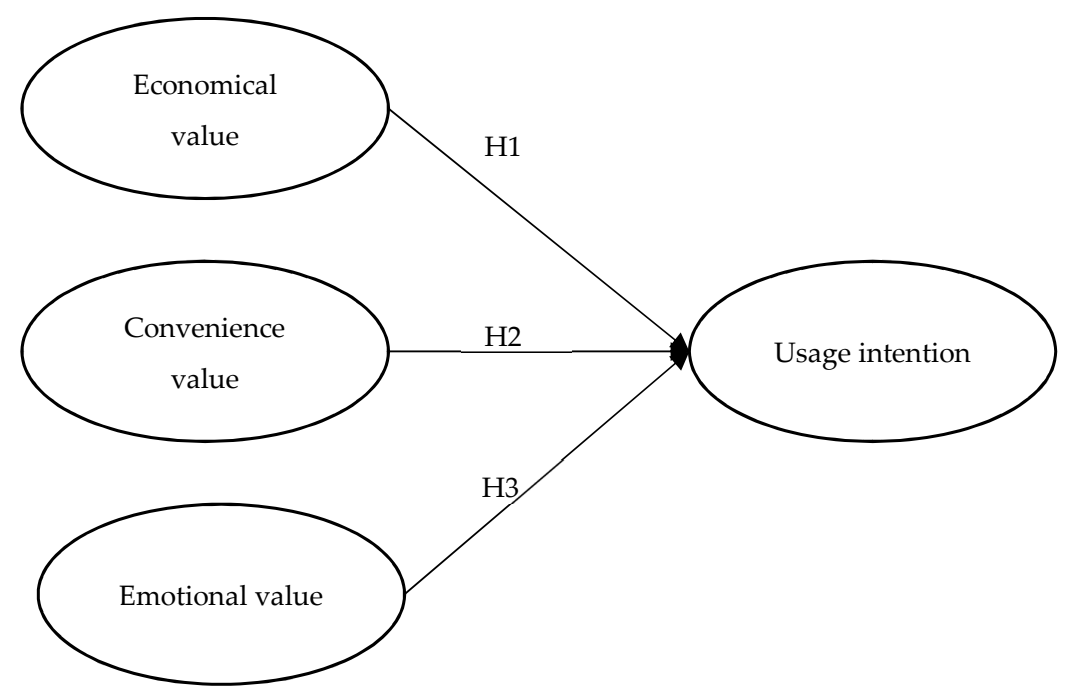

Figure 1. Research model.

\section{Method}

\subsection{Research Setting and Data Collection}

To verify the sets of hypotheses and study model, this study conducted a random sample survey, targeting college students in their 20s who are familiar with IT services and interested in internet-only banks. In all, we distributed 220 questionnaires directly or through the mail and received 200 responses after four weeks. In all, the final analysis used 190 responses, excluding insincere ones. The demographic characteristics of the sample comprised 102 men $(53.7 \%)$ and 88 women $(46.3 \%)$ and all were college students majoring in business administration in Seoul and Daejeon. 


\subsection{Measures}

This study used three dimensions of perceived value: economical value, convenience value, and emotional value. First, economical value is the degree of perceived economic benefits received by customers of the service in comparison to monetary cost. Second, convenience value is the degree of ease with which a customer can purchase services and complete a transaction. Finally, emotional value is the degree of utility from the feelings or affective states that the service generates. By modifying and complementing Pihlström and Brush [11], and Sweeney and Soutar [14], we obtain 10 items for this study. Furthermore, this study modified the definition of usage intention by Grace and $\mathrm{O}^{\prime}$ Cass [26]. All items in each construct were measured using the five-point Likert scale. Table 1 presents the details of the measurement items.

Table 1. Measurement items.

\begin{tabular}{|c|c|c|}
\hline Construct & Items & Reference \\
\hline $\begin{array}{l}\text { Economical } \\
\text { Value }\end{array}$ & $\begin{array}{l}\text { I feel I would be getting my money's worth } \\
\text { I feel that I am getting the service for a reasonable price } \\
\text { The service is good value for the money }\end{array}$ & \multirow{3}{*}{$\begin{array}{l}\text { Pihlström and Brush [8] } \\
\text { Sweeney and Soutar [11] }\end{array}$} \\
\hline $\begin{array}{l}\text { Convenience } \\
\text { Value }\end{array}$ & $\begin{array}{l}\text { Information about the service is convenient to obtain } \\
\text { There are various ways to access } \\
\text { I can easily and quickly purchase the service } \\
\text { The service saves me time and effort }\end{array}$ & \\
\hline $\begin{array}{l}\text { Emotional } \\
\text { Value }\end{array}$ & $\begin{array}{l}\text { Doing something I really like to do } \\
\text { Having fun } \\
\text { Good experience }\end{array}$ & \\
\hline $\begin{array}{l}\text { Usage } \\
\text { Intention }\end{array}$ & $\begin{array}{l}\text { I intend to use the service } \\
\text { I am planning to use the service even in the future } \\
\text { I will probably recommend this service to others }\end{array}$ & Grace and O'Cass [23] \\
\hline
\end{tabular}

\section{Results}

\subsection{Construct Reliability and Validity}

This study verified the reliability of the measurement items for each variable using a Cronbach's alpha coefficient and the values were 0.86-0.91; therefore, the internal consistency of the measurement items was generally ensured. In addition, we performed the exploratory factor analysis (EFA) for construct validation. For measurement variables, we used the principal component analysis to extract configuration factors and the orthogonal rotation method to simplify factor loading values.

According to the EFA results in Table 2, the factor loading values of the instruction variables of each factor are all more than the minimum value of 0.78 , which indicates an appropriate level. The total variance of the four factors explained was $79.91 \%$. In addition, construct reliability (CR) refers to the shared variation between the measured variables of one latent factor; if greater than 0.7 , it is generally accepted to have convergent validity [27]. As Table 2 shows, the minimum value of construct reliability (CR) was 0.88 and that of average variance extracted (AVE) was 0.66 , exceeding the standard and minimum values. This indicates convergent validity between the measured variables.

Table 2. Results for construct reliability and validity.

\begin{tabular}{|c|c|c|c|c|c|c|c|c|}
\hline Construct & & 1 & 2 & 3 & 4 & $\alpha$ & AVE & CR \\
\hline \multirow{3}{*}{ Economical Value } & 1 & & 0.823 & & & \multirow{3}{*}{0.888} & \multirow{3}{*}{0.761} & \multirow{3}{*}{0.905} \\
\hline & 2 & & 0.896 & & & & & \\
\hline & 3 & & 0.897 & & & & & \\
\hline
\end{tabular}


Table 2. Cont

\begin{tabular}{|c|c|c|c|c|c|c|c|c|}
\hline Construct & & 1 & 2 & 3 & 4 & $\alpha$ & AVE & CR \\
\hline \multirow{4}{*}{ Convenience Value } & 1 & 0.808 & & & & \multirow{4}{*}{0.864} & \multirow{4}{*}{0.667} & \multirow{4}{*}{0.889} \\
\hline & 2 & 0.841 & & & & & & \\
\hline & 3 & 0.828 & & & & & & \\
\hline & 4 & 0.791 & & & & & & \\
\hline \multirow{3}{*}{ Emotional Value } & 1 & & & & 0.885 & \multirow{3}{*}{0.876} & \multirow{3}{*}{0.714} & \multirow{3}{*}{0.882} \\
\hline & 2 & & & & 0.860 & & & \\
\hline & 3 & & & & 0.788 & & & \\
\hline \multirow{3}{*}{ Usage Intention } & 1 & & & 0.841 & & \multirow{3}{*}{0.912} & \multirow{3}{*}{0.764} & \multirow{3}{*}{0.906} \\
\hline & 2 & & & 0.912 & & & & \\
\hline & 3 & & & 0.868 & & & & \\
\hline Eigenvalue & & 4.746 & 3.187 & 1.347 & 1.109 & & & \\
\hline Variance $(\%)$ & & 36.511 & 24.512 & 10.363 & 8.529 & & & \\
\hline
\end{tabular}

The discriminant validity of the measurement in this study was also acceptable because the maximum value is 0.43 in the values $(-0.15-0.43)$ of the correlation coefficient among all constructs, which was smaller than the minimum value of 0.81 of the squared average variance extracted $(0.81-0.87)$ [28]. Table 3 presents the correlations and squared average variance extracted for each construct.

Table 3. Results for discriminant validity.

\begin{tabular}{|c|c|c|c|c|}
\hline & 1 & 2 & 3 & 4 \\
\hline Economical Value & 0.872 ** & & & \\
\hline Convenience Value & $-0.158 *$ & $0.817^{* *}$ & & \\
\hline Emotional Value & 0.414 * & 0.251 * & $0.845^{* *}$ & \\
\hline Usage Intention & $0.240 *$ & $0.400 *$ & $0.434 *$ & $0.874^{* *}$ \\
\hline
\end{tabular}

\subsection{Multiple Regression Analysis}

To verify the hypotheses, we conducted a multiple regression analysis. In Table 4, we see the F value of the model showing the effect of the perceived value on individual intention at 25.38 and the regression model formula estimated at a 0.01 significant level was statistically significant. $R^{2}$ was 0.306 , and perceived values explained about $31 \%$ of the usage intention of the internet-only bank service. Thus, as Table 4 shows, all hypotheses were accepted with statistical significance. These results show that consumers obtained more perceived value from internet-only bank services, which increased their usage intention. Therefore, perceived values are an important factor in the acceptance of internet-only bank services.

Table 4. Results of multiple regression analysis.

\begin{tabular}{ccccccc}
\hline Hypothesis & B & $\begin{array}{c}\text { Standard } \\
\text { Error }\end{array}$ & $\begin{array}{c}\text { Standardized } \\
\text { Coefficients }\end{array}$ & t-Value & $p$ & Results \\
\hline $\begin{array}{c}\text { H1: economical value } \rightarrow \\
\text { usage intention }\end{array}$ & 0.142 & 0.055 & 0.188 & 2.581 & 0.011 & Accept \\
\hline $\begin{array}{c}\text { H2: convenience value } \rightarrow \\
\text { usage intention }\end{array}$ & 0.392 & 0.074 & 0.364 & 5.306 & 0.000 & Accept \\
\hline $\begin{array}{c}\text { H3: emotional value } \rightarrow \\
\text { usage intention }\end{array}$ & 0.268 & 0.075 & 0.265 & 3.557 & 0.000 & Accept \\
\hline & $\mathrm{F}=25.384, p<0.000, \mathrm{R}^{2}=0.306$ \\
\hline
\end{tabular}




\section{Conclusions}

This study investigated the impact of consumers' perceived values on internet-only bank service satisfaction and usage intention.

All constructs of perceived value affected the usage intention of internet-only bank services, with convenience value as the most important factor. The results show that the management of and investment in each perceived value dimension will increase usage intention. These findings have important theoretical and practical implications; that is, managing and developing customers' perceived value is an important marketing strategy.

In particular, the reason for convenience value having the greatest effect on usage intention is that ease of use, as revealed by Van der Heijden [19], results in customers recognizing services as useful, which ultimately enhance their intention to use them. Second, internet-only banks provide high interest rates and low lending rates at low costs, because they do not require physical branches or hire employees to meet customers. This is the biggest advantage of internet-only banks. Consumers want to continue using internet-only banks because they can provide necessary banking services at low costs. Third, our results show that emotional value has a positive effect on a customer's intention to use internet-only banks. Consumers enjoy using internet-only banking services, which strengthens intent of use, by developing a positive attitude toward internet-only banks.

This study has the following academic and managerial implications. First, although internet-only banks have been around for a while, this study shows why Korean customers have flocked to them in recent years, which is of academic significance. In addition, by dividing the perceived value into several dimensions, we were able to understand consumer acceptance of new products, services, and distribution channels, in addition to internet-only banks.

Second, when introducing internet-only banks to foreign countries, it is important to understand the needs of early adopters when using new types of service channels. In this regard, this study highlights important aspects in terms of managing early adopters using internet-only banks. In particular, convenience and emotional value play important roles in addition to economic value, despite internet-only banks offering financial services.

Third, considering the lack of academic research on internet-only banks, this study identifies the values and psychology of consumers who use internet-only banks.

Furthermore, the emotional value and convenience of internet-only banking is important in addition to the commonly expected economic value. This study found that banks must invest in providing customers with emotional value and convenience, as these are also important motivations for internet-only bank use. Internet-only banking services will provide new and lasting value by adding various supplementary services, which might attract customers. In addition, it would be necessary to check the service process to maintain the online environment without delays or unnecessary processes that inconvenience customers.

\section{Limitations and Future Research}

This study has some limitations, which could offer suggestions for future studies. First, this study examined college students in their $20 \mathrm{~s}$ who believe themselves to be highly skilled and interested in IT services. However, as these banks target diverse age groups, there is a compelling reason to conduct further research on internet-only banking for consumers with little experience or technology readiness. Thus, future studies will need to examine factors that affect their intended use, reflecting different age groups.

Second, a lack of consumer psychology and behavior research for internet-only banks necessitates further study of the important factors that may affect its acceptance. In other words, a meaningful approach is necessary to discover new personal characteristics and behaviors of consumers using internet-only banks. Furthermore, considering the weakness of internet-only banks, such as protection of personal information, future studies will have to suggest ways to reduce uncertainty and perceived risk to consumers to stimulate their use of internet-only banks. 
Finally, the study surveyed approximately 200 people in their $20 \mathrm{~s}$ in analyzing factors for the acceptance of Internet-only banks. Although those in their $20 \mathrm{~s}$ have judged that they are more familiar with the mobile environment than other age groups, they do not represent all consumers who accept innovative services. For more general findings, future studies will require sample designs to represent the entire consumer population.

Author Contributions: S.H.L. organized the models and finalized the paper, and S.J.A. collected and analyzed the data and prepared the draft.

Funding: This research received no external funding.

Acknowledgments: This research was supported by Hanbat National University and Kyung Hee University.

Conflicts of Interest: The authors declare no conflict of interest.

\section{References}

1. Farhoomand, A.F.; Mak, V. Japan Net Bank: Japan's first internet-only bank-A teaching case. In Proceedings of the 15th Bled Electronic Commerce Conference, Bled, Slovenia, 17-19 June 2002; pp. 672-692.

2. Kurila, J.; Lazuras, L.; Ketikidis, P.H. Message framing and acceptance of branchless banking technology. Electron. Commer. Res. Appl. 2016, 17, 12-18. [CrossRef]

3. Kim, S.H.; Park, T.K. Acceptance factors of financial consumers on Internet Primary Banks. J. Ind. Econ. Bus. 2017, 30, 589-622. [CrossRef]

4. Mustafa, K.; Waheed, A. Impact of alternative factors on usage of telco-led branchless banking services: Empirical evidence from Parkistan. J. Internet Bank. Commer. 2016, 21, 1-19.

5. Hallerman, D. Spinning a New Web of Online Banking. Available online: https:/essentials.news/en/digitalbanking (accessed on 23 August 2019).

6. Watson, C.N. Growth of Internet-only Banks: Brick and Mortar Branches Are Feeling the Byte. NC Bank. Inst. 2000, 4, 345-370.

7. DeYoung, R. The financial performance of pure play Internet banks. Econ. Persp. Fed. Reserve Bank Chic. 2001, 25, 60-73.

8. Zhang, Y.; Chen, X.; Liu, X.; Zhu, N. Exploring trust transfer between internet enterprises and their affiliated internet-only banks: An adoption study of internet-only banks in China. Chin. Manag. Stud. 2018, 12, 56-78. [CrossRef]

9. Kaabachi, S.; Ben Mrad, S.; Petrescu, M. Consumer initial trust toward internet-only banks in France. Int. J. Mark. 2017, 35, 903-924. [CrossRef]

10. Carman, J.M. Values and consumption patterns: A closed loop. Adv. Consum. Res. 1978, 5, 403-407.

11. Pihlström, M.; Brush, G.J. Comparing the perceived value of information and entertainment mobile services. Psychol. Mark. 2008, 25, 732-755. [CrossRef]

12. Zeithaml, V.A. Consumer perceptions of price, quality, and value: A means-end model and synthesis of evidence. J. Mark. 1988, 52, 2-22. [CrossRef]

13. Varki, S.; Colgate, M. The role of price perceptions in an integrated model of behavioral intentions. J. Serv. Res. 2001, 3, 232-240. [CrossRef]

14. Sweeney, J.C.; Soutar, G.N. Consumer perceived value: The development of a multiple item scale. J. Retail. 2001, 77, 203-220. [CrossRef]

15. Sheth, J.N.; Newman, B.I.; Gross, B.L. Why we buy what we buy: A theory of consumption values. J. Bus. Res. 1991, 22, 159-170. [CrossRef]

16. McDougall, G.H.; Levesque, T. Customer satisfaction with services: Putting perceived value into the equation. J. Serv. Mark. 2000, 14, 392-410. [CrossRef]

17. Sweeney, J.C.; Soutar, G.N.; Johnson, L.W. Retail service quality and perceived value: A comparison of two models. J. Retail. Consum. Serv. 1997, 4, 39-48. [CrossRef]

18. Meuter, M.L.; Ostrom, A.L.; Roundtree, R.I.; Bitner, M.J. Self-service technologies: Understanding customer satisfaction with technology-based service encounters. J. Mark. 2000, 64, 50-64. [CrossRef]

19. Van Der Heijden, H. User acceptance of hedonic information systems. MIS Q. 2004, 28, 695-705. [CrossRef]

20. Zhang, X.; Prybutok, V.R. A consumer perspective of e-service quality. IEEE Trans. Eng. Manag. 2005, 52, 461-477. [CrossRef] 
21. Meuter, M.L.; Ostrom, A.L.; Bitner, M.J.; Roundtree, R. The influence of technology anxiety on consumer use and experiences with self-service technologies. J. Bus. Res. 2003, 56, 899-906. [CrossRef]

22. Reichheld, F.F.; Schefter, P. E-loyalty: Your secret weapon on the web. Harv. Bus. Rev. 2000, 78, $105-113$.

23. Hirschman, E.C.; Holbrook, M.B. Hedonic consumption: Emerging concepts, methods and propositions. J. Mark. 1982, 46, 92-101. [CrossRef]

24. Turel, O.; Serenko, A.; Bontis, N. User acceptance of wireless short messaging services: Deconstructing perceived value. Inf. Manag. 2007, 44, 63-73. [CrossRef]

25. Venkatesh, V.; Thong, J.Y.; Xu, X. Consumer acceptance and use of information technology: Extending the unified theory of acceptance and use of technology. MIS Q. 2012, 36, 157-178. [CrossRef]

26. Grace, D.; O'Cass, A. An examination of the antecedents of repatronage intentions across different retail store formats. J. Retail. Consum. Serv. 2005, 12, 227-243. [CrossRef]

27. Bagozzi, R.P.; Yi, Y. On the evaluation of structural equation models. J. Acad. Mark. Sci. 1988, 16, 74-94. [CrossRef]

28. Fornell, C.; Larcker, D.F. Evaluating structural equation models with unobservable variables and measurement error. J. Mark. Res. 1981, 18, 39-50. [CrossRef]

(C) 2019 by the authors. Licensee MDPI, Basel, Switzerland. This article is an open access article distributed under the terms and conditions of the Creative Commons Attribution (CC BY) license (http://creativecommons.org/licenses/by/4.0/). 